\title{
Implementasi Sistem Penyimpanan Terpusat Menggunakan Pydio 8.0 Community pada Universitas Islam Batik Surakarta
}

\author{
Fajar Kurnia \\ Jurusan Informatika Universitas Muhammadiyah Surakarta (UMS) Surakarta, Indonesia \\ ofafajar8@gmail.com
}

Dr. Heru Supriyono, M.Sc.

Jurusan Informatika Universitas Muhammdiyah Surakarta(UMS) Surakarta, Indonesia

Heru.supriyono@ums.ac.id

Abstraksi - Perkembangan teknologi pada era digital saat ini berkembang dengan sangat pesat terutama pada sektor penyimpanan data. Salah satu contoh perkembangan teknologi pada sektor penyimpanan data adalah teknologi private cloud storage. Teknologi private cloud storage masih belum banyak dimanfaatkan pada lembaga atau instansi dalam bidang pendidikan sedangkan teknologi private cloud storage merupakan alternatif bagi lembaga atau instansi dalam bidang pendidikan untuk menyimpan ataupun berbagi data tanpa cemas akan virus. Tujuan penelitian ini adalah merancang serta mengimplementasikan pemanfaatan private cloud storage sebagai media penyimpanan terpusat pada Universitas Islam Batik Surakarta(UNIBA) untuk menyelesaikan permasalahan seperti kerusakan data oleh virus serta mengefisienkan dalam berbagi data. Pada penelitian ini software private cloud storage yang digunakan adalah Pydio 8.0 Community yang dapat meminimalisir kerusakan data oleh virus serta mengefisienkan dalam berbagi data. Hasil dari penelitian ini merupakan sistem penyimpanan terpusat dengan software Pydio 9.0 Community yang dapat diakses melalui web browser, desktop dan smartphone diuji melalui tiga tahap yaitu pengujian kemampuan komputer server, koneksi antara client dan server serta pengujian keamanan komputer server. Berdasarkan hasil pengujian yang telah dilakukan memperoleh hasil kemampuan server dalam membalas permintaan client berkisar 0,6 detik dengan rata-rata kecepatan koneksi antara client dengan server 460kbps. Untuk keamanan komputer server, folder yang ada sudah dapat dienkripsi dengan baik oleh sistem. Hasil pengujian tersebut menunjukkan bahwa pemanfaatan teknologi private cloud storage dengan software Pydio 8.0 Community dapat memecahkan masalah yang ada pada suatu lembaga atau instansi dalam bidang pendidikan dalam kasus ini pada Universtitas Islam Batik Surakarta.

\section{Katakunci-private cloud storage;cloud computing;Pydio 8.0 Community}

\section{PendahuluaN}

Seiring dengan perkembangan teknologi informasi yang sangat pesat pada era digital saat ini, data merupakan hal yang sangat penting bagi suatu lembaga atau instansi yang bergerak dalam bidang pendidikan, ekonomi, kesehatan dan lain sebagainya[1]. Data pada suatu lembaga atau instansi perlu dijaga serta dimanajemen dengan baik. Terlebih untuk lembaga atau instansi yang mempunyai data yang sangat banyak. Diperlukan tempat penyimpanan khusus untuk mencadangkan data-data tersebut yang bersifat sementara agar tidak khawatir jika ada data yang disimpan di media penyimpanan lain hilang atau rusak. Universitas Islam Batik Surakarta adalah perguruan tinggi swasta yang telah berdiri sejak tahun 1988. Universitas Islam Batik Surakarta memiliki 4 fakultas, diantaranya fakultas hukum, fakultas pertanian, fakultas ekonomi dan fakultas pascasarjana dengan jumlah mahasiswa aktif 2568 orang dan 125 orang staff pengajar beserta staff karyawan. Saat ini mahasiswa dan staff menyimpan dan bertukar informasi (data) dengan menggunakan flashdisk atau harddisk. Permasalahan yang sering muncul bila 
menggunakan media penyimpanan tersebut adalah hilang atau rusaknya data yang tersimpan serta dalam bertukar data harus dalam tempat yang sama.

Pada penelitian ini peneliti akan mencoba mengatasi permasalahan tersebut dengan cara membuat sistem penyimpanan terpusat yang bersifat sementara pada sisi server. Memanfaatkan pengembangan teknologi cloud computing yaitu private cloud storage berbasis web yang dapat mencegah hilang atau rusaknya data disebabkan oleh virus dan memberikan kemudahan bagi penggunanya dalam hal menyimpan serta membagikan data yang dimiliki. Cloud storage merupakan media penyimpanan di awan, dimana data tersimpan di komputer server yang tersedia.

Layanan penyimpanan awan atau cloud storage menyediakan ruang penyimpanan jaringan virtual online menggunakan teknologi komputasi. Pengguna dapat menyimpan data di folder lokal dan mengambilnya dari perangkat yang terhubung ke internet terlepas dari lokasinya[2]. Sedangkan cloud computing bisa didefinisikan sebagai sistem komputer yang saling terhubung dan terdistribusi terdiri dari kumpulan sumber daya yang terhubung satu sama lain berdasarkan Service Level Agreements(SLA) antara penyedia layanan dan komsumen[3]. Mekanisme pengaksesan cloud storage yaitu pengguna menggunakan web browser, desktop dan smartphone melalui internet untuk mengakses data, berkas, program dan lain sebagainya yang dimiliki oleh pengguna tersebut.

Penelitian yang dipublikasikan ini mempunyai keunggulan dari penelitian sebelumnya yaitu aplikasi yang digunakan untuk cloud yaitu aplikasi Pydio 8.0 Community. Pydio memiliki beberapa kelebihan diantaranya adalah user interface pada aplikasi ini terbilang lebih baik dibandingkan dengan aplikasi cloud lainnya. Selain itu, sisi keamanan Pydio terintergrasi dengan enkripsi yang dimilki oleh linux yaitu Encrypted File System(EncFS). EncFS merupakan enkripsi virtual yang menyimpan data terenkkripsi di direktori berbeda dengan data yang tidak terenkripsi[4].
Tujuan penelitian ini yaitu peneliti mencoba menerapkan pengembangan teknologi cloud computing yaitu private cloud storage untuk mengatasi permasalahan seperti kerusakan data dan mempermudah dalam berbagi data. Selain itu teknologi cloud computing dianggap sebagai aplikasi yang sangat berguna untuk suatu organisasi atau lembaga karena keuntungannya seperti penghematan biaya jangka panjang, akses data yang mudah pada waktu tertentu dan ekonomis[5]. Penerapan teknologi cloud computing sudah banyak dilakukan untuk dijadikan solusi media penyimpanan serta pengolahan data. Salah satu penerapan dalam hal tersebut yaitu penelitian yang dilakukan oleh Ferdiana, Nugroho \& Irma yang menyatakan bahwa pemanfaatan teknologi cloud computing dapat memanajemen sistem pengarsipan menjadi lebih baik, serta mempermudah pengolahan data dengan banyak pengguna[6].

\section{Metode Penelitian}

Langkah-langkah yang dilaksanakan yaitu analisis kebutuhan hardware, analisis kebutuhan software, perancangan sistem, implementasi, dan pengujian.

\section{A. Analisis kebutuhan hardware}

Sistem private cloud storage di Universitas Islam Batik Surakarta akan digunakan oleh 125 orang staff serta mahasiswa dalam kegiatan praktikum. Penelitian ini membutuhkan satu buah komputer sebagai server dengan spesifikasi yang ditunjukkan pada tabel 1 .

TABEL I. INFORMASI SPESIFIKASI KOMPUTER SERVER

\begin{tabular}{|c|c|}
\hline Processor & Intel ${ }^{\circledR}$ Core $^{\mathrm{TM}}$ i5-6400 \\
\hline Hardisk & 1TB HDD \\
\hline RAM & 4GB DDR4 \\
\hline VGA Card & NVIDIA $®$ GeForce $®$ 930M \\
\hline Router & Mikrotik RB 750 hEXlite \\
\hline
\end{tabular}

\section{B. Analisis kebutuhan software}

Penelitian ini menggunakan software yaitu sistem operasi Linux Ubuntu 14.04 Lts. Linux 
Ubuntu merupakan sistem operasi open source dimana pengguna bebas dapat memodifikasi serta memakai tanpa harus membeli lesensi. Pada sistem operasi tersebut diinstall software yang ditunjukkan pada tabel 2.

TABEL II. INFORMASI APLIKASI PENDUKUNG PADA SISTEM OPERASI

\begin{tabular}{|c|c|}
\hline $\begin{array}{c}\text { Operating } \\
\text { system }\end{array}$ & $\begin{array}{c}\text { Linux Ubuntu } 14.04 \\
\text { Lts }\end{array}$ \\
\hline Database & MySQL server \\
\hline Web server & Apache2, PHP5 \\
\hline Service & $\begin{array}{c}\text { SSH, SSL, ICMP, } \\
\text { EncFS }\end{array}$ \\
\hline $\begin{array}{c}\text { Software Cloud } \\
\text { Storage }\end{array}$ & $\begin{array}{c}\text { Pydio 8.0 Community } \\
\text { WebPanel }\end{array}$ \\
\hline
\end{tabular}

\section{Perancangan sistem}

Alur pertukaran data dijelaskan pada gambar 1.

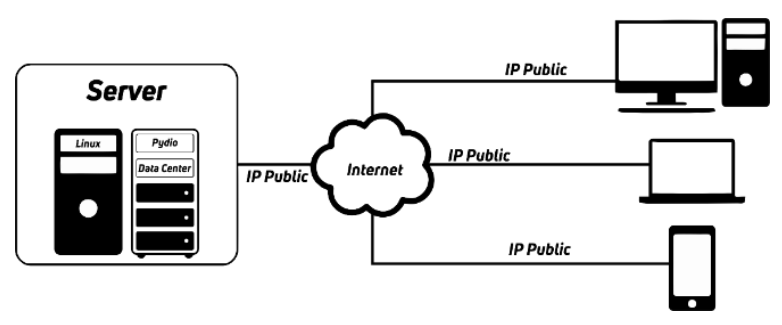

Gambar 1. Rancangan private cloud storage

Pada gambar 1 menjelaskan secara singkat mekanisme kerja dari private cloud storage menggunakan software Pydio yang ditempatkan pada komputer server. Pengguna mengakses server Pydio melalui internet atau IP publik yang disediakan oleh router Mikrotik. Sebelumnya paket tersebut melewati modem Huwei Telkom terlebih dahulu dan IP user menjadi satu network dengan IP lokal. Router Mikrotik kemudian mengalihkan IP publik tersebut ke port Pydio. User dapat mengakses Pydio melalui laptop, desktop dan smartphone.

\section{$D$. Implementasi sistem}

Tahap pertama dalam implementasi sistem yakni mengkonfigurasi modem Huawei Telkom menjadi mode bridge pada koneksi WAN. Konfigurasi tersebut memilih satu port yang tersambung dengan router Mikrotik RB 750hEXlite. Port tersebut menjadi port yang menghubungkan antara internet dengan router Mikrotik RB 750hEXlite yang sebelumnya di autentifikasi dari Telkom.

Kemudian, mengkonfigurasi pada router Mikrotik RB $750 \mathrm{hEXlite} \mathrm{agar} \mathrm{router}$ mendapatkan IP publik. Caranya dengan konfigurasi PPPOE Client lalu mengaktifkan Dynamic Domain Name System(DDNS) pada tab IP-cloud. Apabila tahap tersebut sudah diimplementasikan router sudah dapat di remote atau dikontrol dari jarak jauh dengan catatan router tetap menyala. Kemudian mengatur rule pada router Mikrotik 750hEXlite agar langsung menyambungkan dengan IP Pydio. Selain rule tersebut untuk langsung menyambungkan ke IP Pydio juga membuat Virtual Private Network(VPN). Cara untuk membuat VPN yaitu membuat akun pada tab PPP kemudian pilih bar secrets dan klik tanda "+" isikan username serta password pada kolom yang tersedia. Lalu tentukan jangka $I P$ yang dapat menggunakan koneksi pada VPN serta mengaktifkan Secure Socket Tunelling Protocol(SSTP). Setelah itu membuat sertifikat untuk server, client, dan Certificate Authority(CA) pada tab certificates.

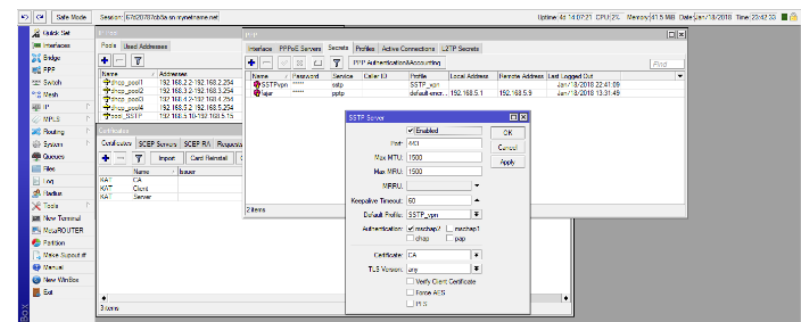

Gambar 2. Konfigurasi VPN

Tahap selanjutnya yaitu melakukan installasi Operating System Linux Ubuntu 14.04 Lts pada komputer server. Setelah installasi Operating System selesai software seperti Apache2 web server, php5, MySQL, Pydio dan software lainnya juga diinstall dalam 
komputer server. Berikut penjelasan dari Operating System dan software tersebut.

\section{$E$. Installasi operating system ubuntu 14.04 lts}

Operating System diinstall menggunakan media falshdisk serta menggunakan software YUMI-2.0.5.0 untuk membuat bootable operating system. Selanjutnya mengatur partisi untuk home, root, swap operating system Linux Ubuntu. Kemduian, tinggal mengikuti langkah-langkah yang sudah ada pada installasi operating system Linux Ubuntu.

\section{$F$. Installlasi Tasksel}

Setelah sistem operasi terinstall di komputer server, langkah selanjutnya adalah menginstall paket Tasksel. Tasksel adalah paket yang disediakan oleh linux berisi beberapa aplikasi diantaranya seperti, OpenSSH Server, DNS Server, LAMP Server, Mail Serverl dan lain sebagainya. Untuk menginstall paket tasksel tersebut dengan memasukkan perintah apt-get install tasksel pada terminal Ubuntu 14.04 Lts x64. Setelah menjalankan perintah tersebut, kita dapat memilih aplikasi mana saja yang ingin diinstall pada komputer server. Pada penelitian ini yang pertama dibutuhkan adalah aplikasi $L A M P$ Server yang didalamnya sudah termasuk MySQL Server, Apache2 Web Server, PHP5. Pada saat proses installasi $L A M P$ Server akan diminta untuk mengisi username dan password untuk MySQL Server. Kemudian apabila telah selesai installasi cek apakah semua sudah terinstall dengan benar dengan cara memasukan perintah $p h p-v$ dan apache $2-v$ pada terminal Ubuntu 14.04 Lts x64. Tahap selanjutnya adalah membuat database untuk menampung Pydio pada $M y S Q L$ Server. Adapun langkah-langkah untuk membuat database memasukkan perintah sebagai berikut

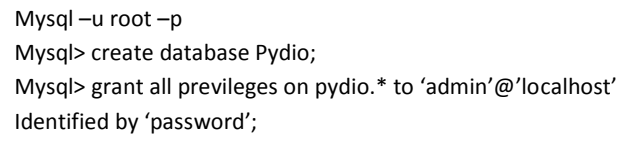

Gambar 3. Perintah pembuatan database

\section{$G$. Installasi openssh server}

Selanjutnya menginstall OpenSSH Server. OpenSSH Server merupakan alat konektivitas untuk meremote komputer server dengan protocol Secure Shell(SSH). Cara untuk menginstall OpenSSH Server dengan cara yang sama dengan menginstall paket Tasksel. Tetapi nantinya memilih OpenSSH Server pada tampilan ini

You can choose to install one or more of the following predefined
Collections of software.
Choose software to install:
[ ] Basic Ubuntu Server
[*] OpenSSH Server
[ ] DNS Server
[*] LAMP Server
[ ] Mail Server
[ ] PostgreSQL Server

\section{Gambar 4. Tampilan pemilihan} software pada Tasksel

Selanjutnya hanya tinggal mengikuti langkah yang ada. Kemudian ubah port default SSH dengan memasukkan perintah nano letc/sshd_config dan cari port default SSH yaitu port 22 diubah menjadi port 2894.

\section{H.Konfiguras openssl}

Agar koneksi antara server dan client lebih aman maka diperlukan protokol yang dapat memastikan koneksi yang terjadi secara online telah di enkripsi dengan baik. Protokol yang digunakan adalah Secure Socker Layer(SSL). Untuk mengaktifkannya dengan cara a2enmod ssl dan membuat direktori khusus SSL pada direktori Apache2. Kemudian membuat sertifikat khusus SSL dengan memasukkan perintah berikut

openssl req $-\mathrm{x} 509$-nodes -days 730 -newkey rsa:2048 -keyout /etc/apache2/ssl/apache.key -out

\section{Gambar 5. Perintah pembuatan} sertifikat $S S L$

Selanjutnya ubah file default-ssl.conf dengan mengganti direktori SSLCertificateFile dan SSLCertificateKeyFile sesuai dengan direktori ketika membuat sertifikat. Setelah itu menambahkan file pydio-ssl.conf pada direktori letc/apache2/sites-available dan 
restart apache 2 untuk mengaktifkan konfigurasi.

\section{Installasi Ajenti}

Tahap selanjutnya adalah menginstall Ajenti yang digunakan untuk memanajemen komputer server berbasis web. Aplikasi ini dapat membantu admin dalam memantau sumber daya yang ada pada komputer server dari luar kampus. Cara untuk menginstallnya adalah dengan cara memasukkan perintah berikut

wget-O- https://raw.github.com/ajenti/ajenti1.x/scripts/installubuntu.sh | sudo sh

Gambar 6. Perintah installasi Ajenti

pada terminal Ubuntu 14.04 Lts X64.

\section{$J$. Installasi encrypted file system(EncFS)}

EncFS adalah enkripsi yang dimilik oleh Linux untuk mengamankan data. Data yang dienkripsi tersimpan pada direktori yang berbeda dengan data yang didekripsi sehingga keamanan data terjamin. Untuk cara menginstallnya dengan memasukkan perintah apt-get install encfs pada terminal Ubuntu 14.04 Lts X64. Langkah selanjtunya yaitu membuat folder untuk data terenkripsi dan data yang tidak terenkripsi dengan cara $m k d i r$ $-p /$ crypt dan $m k d i r-p$ /decrypt pada direktori /home/nama_komputer/ kemudian ikuti langkah yang ada. Setelah folder selesai dibuat, export file XML EncFS dengan memasukkan perintah

Export ENCFS6_CONFIG=/home/nama_komputer/crypt/.encfs6.xm

Gambar 7. Perintah export file XML

pada terminal Ubuntu 14.04 Lts X64. Setelah itu hanya tinggal mengaktifkan plugin dan masukkan direktori yang sama pada saat export file XML serta password pada setting di Pydio 8.0 Community. Lalu konfigurasi user untuk menjalankan beberapa perintah tanpa harus memberikan password. Untuk konfigurasi hanya perlu menjalankan perintah berikut pada direktori /etc/sudoers/.

www-data ALL = NOPASSWD:

/usr/bin/encfs,/usr/bin/encfsctl,/bin/umount
Gambar 8. Perintah konfigurasi user

\section{K. Konfigurasi internet control message protocol(ICMP)}

Selanjutnya adalah konfigurasi ICMP untuk mencegah serangan lalu lintas jaringan dengan banyak data. Cara untuk mengaktifkannya dengan mengubah konfigurasi sysctl mengganti parameter 0 menjadi 1 pada icmp_echo_ignore_all. Perintah untuk mengaktifkannya sebagai berikut

echo 1 >/proc/sys/net/ipv4/icmp_echo_ignore_all

Gambar 9. Perintah ICMP

pada terminal Ubuntu 14.04 Lts X64.

\section{Installasi pydio 8.0 community}

Tahap terakhir dalam implementasi sistem adalah menginstall Pydio 8.0 Community. Pertama-tama download paket Pydio 8.0 Community dari website resmi Pydio. Kemudian unzip file Pydio dengan cara unzip pydio-core-8.0.1.zip pada terminal Ubuntu 14.04 Lts x64 dan tunggu hingga selesai. Lalu pindahkan file tersebut ke direktori /var/www/html/pydio/. Kemudian edit file pydio-ssl.conf pada direktori letc/apache2/sites-available/pydio-ssl.conf dengan konfigurasi berikut

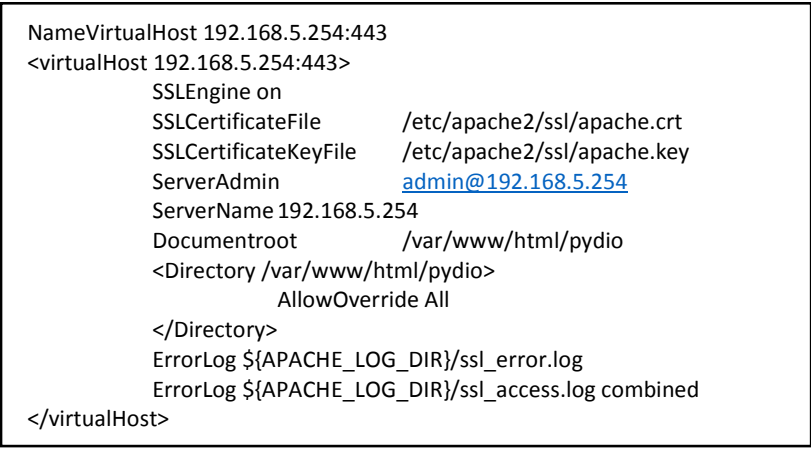

Gambar 10. Konfigurasi pada pydio.comf

Setelah itu tambahkan ip address serta ServerName yang sudah ada pada konfigurasi pydio.conf ke direktori /etc/hosts. Selanjutnya restart service apache 2 dan service PHP5 dengan cara memasukan perintah systemctl restart apache2.service php5.0-fpm.service mysql.service pada terminal Ubuntu $14.04 \mathrm{Lts}$ x64. Tahap selanjutnya adalah membuka 
Pydio dengan domain https://192.168.5.254 dan membuat username, password untuk admin dari Cloud Pydio.

\section{HASIL DAN PEMBAHASAN}

Dari implementasi tersebut penelitian ini menghasilkan sebuah sistem penyimpanan di awan atau cloud storage yang berfungsi untuk mencegah kerusakan data dan mempermudah dalam berbagi data di UNIBA. Sistem ini dapat diakses dalam bentuk website, software sinkronasi desktop dan aplikasi pada smartphone. Selain itu sistem penyimpanan ini dibekali beberapa aplikasi maupun service tambahan guna mempermudah pekerjaan seorang admin pada sistem ini. Adapun aplikasi dan service tambahan tersebut meliputi Ajenti panel, enkripsi folder serta layanan VPN dengan SSTP.

Ajenti panel dapat digunakan admin untuk memantau sumber daya komputer server tanpa harus berada di lokasi komputer server. Admin hanya mengakses https://servercloud.aliyastore.id: 8000 untuk mengetahui sumber daya komputer server seperti berapa persen kegunaan Central Processing Unit(CPU) dikala diakses dan masih banyak lagi. Kemudian apabila admin ingin melihat ataupun meremote jaringan dari luar dapat menggunakan layanan VPN yang tersedia. Lalu untuk keamanan data pada sistem ini dibekali dengan sebuah enkripsi yaitu EncFS yang dapat mengenkripsi folder data admin maupun pengguna.

Sistem ini dapat diakses melalui web browser dengan memasukkan alamat https://servercloud.aliyastore.id dan apabila pengguna terhubung dengan jaringan lokal untuk mengaksesnya memasukkan alamat https://192.168.5.254. Untuk kemudahan, sistem ini dapat diakses melalui desktop atau laptop pengguna dengan mendownload software PydioSync. Lalu pilih koneksi https dan masukkan alamat servercloud.aliyastore.id serta username dan password masing-masing. Apabila pengguna tidak membawa laptop, sistem ini dapat diakses melalui smartphone pengguna. Caranya mendownload aplikasi Pydio atau PydioPro pada appstore maupun playstore. Kemudian pilih koneksi https dan masukkan alamat servercloud.aliyastore.id serta username dan password pada kolom yang tersedia.

Dari hasil tersebut sistem ini dilakukan pengujian agar sistem ini berjalan sesuai apa yang diharapkan. Pengujian tersebut meliputi pengujian kemampuan komputer server, koneksi antara client dengan server dan pengujian keamanan komputer server.

\section{A. Pengujian kemampuan komputer server}

Pengujian kemampuan komputer server dilakukan dengan simulasi software tools yang merupakan bawaan dari Apache yang bernama Apache Bench. Apache Bench adalah sebuah tools untuk mensimulasikan kunjungan pada sebuah web server. Saat simulasi berlangsung user diatur sebanyak 100 serta request diatur sebanyak 1000 mengakses dalam waktu bersamaan. Hasil yang didapatkan adalah seperti gambar dibawah ini

\begin{tabular}{|c|c|c|}
\hline \multirow{3}{*}{$\begin{array}{l}\text { Server Software: } \\
\text { Server Hostname: } \\
\text { Server Port: }\end{array}$} & \\
\hline & \multirow{2}{*}{\multicolumn{2}{|c|}{$\begin{array}{l}\text { serverpy.com } \\
80\end{array}$}} \\
\hline & & \\
\hline \multirow{2}{*}{$\begin{array}{l}\text { Document Path: } \\
\text { Document Length: }\end{array}$} & \multicolumn{2}{|l|}{ / } \\
\hline & \multicolumn{2}{|l|}{1931 bytes } \\
\hline Concurrency Level: & \multicolumn{2}{|l|}{100} \\
\hline \multirow{2}{*}{ Time taken for tests: } & \multicolumn{2}{|l|}{40.243 seconds } \\
\hline & \multicolumn{2}{|l|}{1000} \\
\hline Failed requests: & \multicolumn{2}{|l|}{793} \\
\hline \multicolumn{3}{|c|}{ (Connect:0, Receive:0, Length:793, Exceptions:0) } \\
\hline Non-2xx responses: & \multicolumn{2}{|l|}{32} \\
\hline Total transferred: & \multicolumn{2}{|l|}{2064012 bytes } \\
\hline HTML transferred: & \multicolumn{2}{|l|}{1878990 bytes } \\
\hline Requests per second: & \multicolumn{2}{|l|}{$24.85[\# /$ sec] (mean) } \\
\hline Time per request: & \multicolumn{2}{|c|}{$4024.300[\mathrm{~ms}]($ mean) } \\
\hline Time per request: & \multicolumn{2}{|c|}{$40 . .243[\mathrm{~ms}]$ (mean, across all concurrent requests) } \\
\hline Transfer rate: & \multicolumn{2}{|c|}{$50,11[$ Kbytes/sec] received } \\
\hline \multicolumn{3}{|l|}{ Connection Times (ms) } \\
\hline & mean[+/-sd] median & $\max$ \\
\hline connect: $\quad 2$ & $36313.5 \quad 2 \quad 3007$ & \\
\hline processing: 279 & 17965212.9610 & \\
\hline waiting: $\quad 279$ & $17955213.0610 \quad 30705$ & \\
\hline total: & $281 \quad 18315233.6613$ & 33351 \\
\hline \multicolumn{3}{|c|}{ percentage of the request server within a certain time (ms) } \\
\hline $50 \%$ & \multicolumn{2}{|l|}{613} \\
\hline $66 \%$ & \multicolumn{2}{|l|}{632} \\
\hline $75 \%$ & \multicolumn{2}{|l|}{814} \\
\hline
\end{tabular}

Gambar 11. Hasil pengujian

Dari hasil tersebut dapat terlihat bahwa dengan simulasi 100 user dan 1000 Request yang diterima server, jenis server yang dipakai adalah Apache dengan nama host serverpy.com, memakai port 80 berada di direktori root, besar ukuran dokumen 1931 bytes, waktu yang dibutuhkan untuk simulasi 40,25 detik, total transfer 2065012 bytes, 
HTML yang telah tertransfer 1878990 bytes, rata-rata per detiknya user yang melakukan request berkisar 25, rata-rata waktu yang dibutuhkan untuk request berkisar 40,25 ms dengan kecepatan transfer 50,1 kilobytes dan waktu paling cepat untuk melakukan feedback 0,6 detik sedangkan waktu terlamanya mencapai 30,3 detik.

\section{B. Pengujian koneksi antara client dengan server}

Pada pengujian ini dilakukan dengan cara mengkoneksi antara client dengan server menggunakan platform yang berbeda. Pengujian tersebut menghasilkan kecepatan transfer data antara client dengan server pada saat upload dan download sebuah file. Hasil dari pengujian ini dijelaskan pada tabel 3.

TABEL III. HASIL PENGUJIAN KONEKSI

\begin{tabular}{|l|l|l|l|l|}
\hline $\begin{array}{l}\mathrm{N} \\
\mathrm{O}\end{array}$ & Pengguna & $\begin{array}{l}\text { Platfor } \\
m\end{array}$ & Upload & $\begin{array}{l}\text { Downloa } \\
d\end{array}$ \\
\hline 1 & Pengguna 1 & Desktop & $\begin{array}{l}690 \mathrm{kbp} \\
\mathrm{s}\end{array}$ & $190 \mathrm{kbps}$ \\
\hline 2 & Pengguna 2 & $\begin{array}{l}\text { Web } \\
\text { browser }\end{array}$ & $\begin{array}{l}710 \mathrm{kbp} \\
\mathrm{s}\end{array}$ & $210 \mathrm{kbps}$ \\
\hline 3 & Pengguna 3 & Android & $\begin{array}{l}310 \mathrm{kbp} \\
\mathrm{s}\end{array}$ & $150 \mathrm{kbps}$ \\
\hline 4 & Pengguna 4 & IOS & $\begin{array}{l}300 \mathrm{kbp} \\
\mathrm{s}\end{array}$ & $149 \mathrm{kbps}$ \\
\hline
\end{tabular}

Dari hasil tersebut terlihat bahwa rata-rata kecepatan koneksi antara client dengan server menggunakan smartphone berkisar $305 \mathrm{kbps}$ untuk proses upload sebuah file sedangkan untuk download rata-rata kecepatan berkisar 149kbps. Rata-rata kecepatan koneksi pada desktop berkisar 700kbps untuk proses upload dan untuk proses download berkisar 200kbps.

\section{Pengujian keamanan server}

Pengujian keamanan server dilakukan dengan mencoba menganalisa lalu lintas jaringan komputer serta menangkap paket-paket data/informasi yang melewati jaringan yang dimonitor. Dalam pengujian ini menggunakan software wireshark yang dapat menangkap informasi yang dibutuhkan. Hasil yang didapatkan dari monitoring ditunjukkan pada gambar 12.

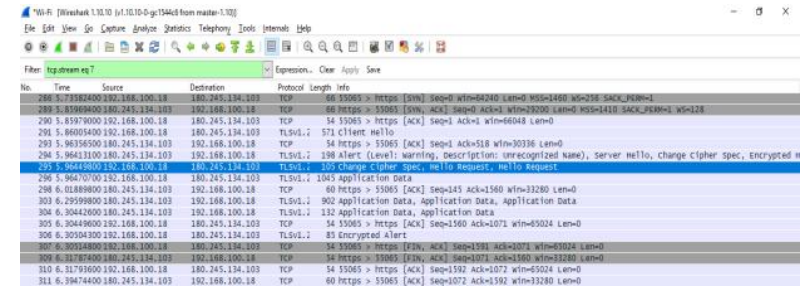

Gambar 12. Hasil monitoring paker jaringan

Dari hasil tersebut menunjukkan bahwa SSL yang sudah dikonfigurasi pada komputer server sudah berhasil mengenkripsi data pada saat login ke Pydio. Kemudian untuk menghindari serangan Distributed Denial of Service(DDOS) dalam bentuk mengirimkan sebuah paket dengan ukuran lebih besar dengan cara mengaktifkan ICMP. Pengujian ini dilakukan dengan cara mengirimkan paket ke IP Pydio.

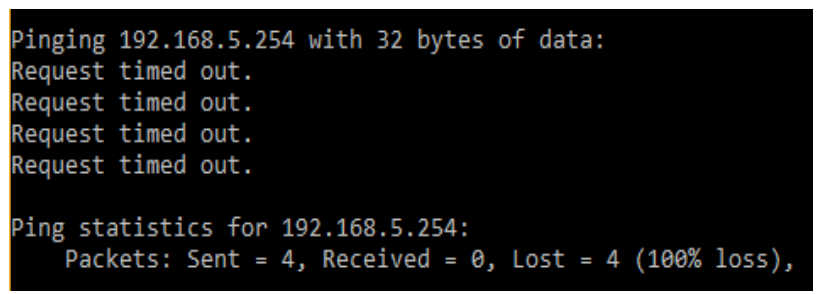

Gambar 13. Hasil pengujian mengirimkan paket

pada gambar 13 menunjukkan bahwa ketika mengirimkan paket ke IP Pydio tidak bisa dikarenakan sudah dicegah dengan ICMP. Selanjutnya untuk keamanan data, pengujian dilkukan dengan mengenkripsi sebuah folder sehingga terenkripsi dengan baik.

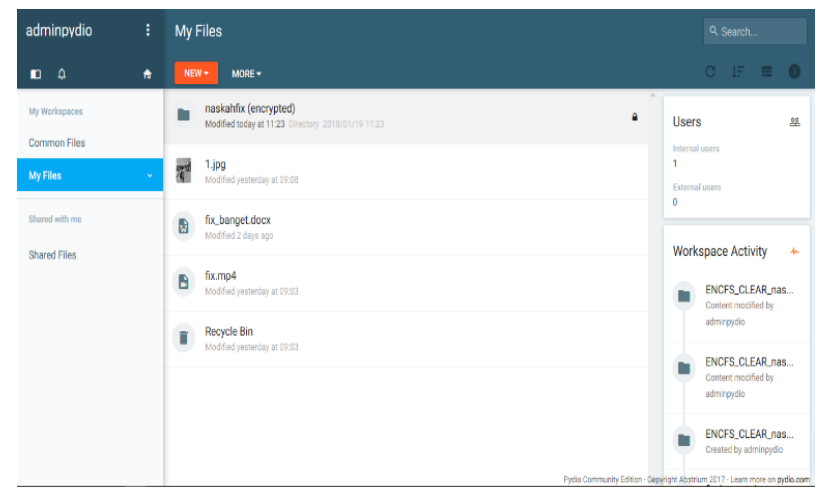

Gambar 14. Hasil enkripsi folder

Dari gambar 14 menunjukkan bahwa folder yang ada sudah terenkripsi dengan baik oleh 
service EncFS dan keamanan data sudah teruji.

\section{KESIMPULAN}

Dari hasil penelitian yang telah dilakukan dapat diambil kesimpulan bahwa dengan adanya sistem private cloud storage dengan menggunakan Pydio 8.0 Community di UNIBA, dapat membantu para dosen, staff dan mahasiswa dalam menyimpan dan berbagi data. Mereka dapat menyimpan dengan mudah melalui smartphone masing-masing dan berbagi data ke pengguna lain tanpa cemas akan virus yang dapat merusak data tersebut. Selain itu para dosen, staff dan mahasiswa tidak khawatir lagi dengan kemanan datanya. Dikarenakan sistem ini sudah mampu mengenkripsi sebuah folder sehingga keamanan data tidak diragukan lagi.

Hasil penelitian tersebut masih jauh dari kata sempurna. Maka dari itu, peneliti menyarankan kedepannya sistem ini dapat dikembangkan lebih baik lagi. Dari segi hardware perlu diupgrade agar kinerja sistem meningkat, meningkatkan keamanan jaringan yang ada, menambahkan halaman pendaftaran bagi pengguna baru serta merawat sistem dengan semestinya

\section{Daftar Pustaka}

[1] Muhammad Ibrahim., "Analisis Dan Implementasi Owncloud Sebagai Media Penyimpanan Pada Yayasan Salman AlFarisi Yogyakarta", Jurnal Ilmiah Dasi, 2013

[2] Lim, C., Kang, M., \& Lee, S., "Design and Implementatio of a Collaborative TeamBased Cloud Storage System", Journal of Supercomputing, 2016.

[3] Kaur, R., \& Kaur, J., "Cloud Computing Security. İssues and Itśs Solution: A review Computing for Sustainable, Global Development (INDIACom)", Internatioal Conference, 2015.

[4] V.i Gough., "EncFS: An Encrypted Filesystem for januari 2018].

[5] Amron, M, T., Ibrahim, R., \& Chuprat, S., "A Review on Cloud Computing Acceptance Factors", Elsevier, 2017.

[6] Ferdiana, R., Nugroho, L, E., \& Irma., "Implementasi Cloud Computing sebagal Digital Aset Management(DAM) di Isstana Kepresidenan Yogyakarta", Prosiding seminar nasional GEOTIK, 2017. 